\title{
ACERCA DEL DERECHO FUNDAMENTAL AL PLAZO RAZONABLE DE DURACIÓN DEL PROCESO PENAL*
}

Daniel R. Pastor

1. El problema y su importancia; 2. La evolución de la cuestión y su regulación positiva; 3. La suerte del derecho al plazo razonable en la aplicación práctica: la opinión dominante; 4. La interpretación del plazo razonable propuesta en este trabajo: 4.1. Introducción; 4.2. El carácter legal del plazo razonable: 4.2.1. El argumento del mandato expreso del orden jurídico internacional; 4.2.2. El argumento del mandato expreso del principio del Estado de derecho; 4.2.3. El argumento del principio nulla coactio sine lege; 4.2.4. El argumento del principio de legalidad material; 4.2.5. El argumento de la división de poderes; 4.2.6. Primeras conclusiones intermedias; 4.3. Las consecuencias jurídicas del cumplimiento del plazo razonable: 4.3.1. El plazo razonable con los efectos de un plazo procesal; 4.3.2. El cumplimiento del plazo razonable como impedimento procesal; 4.3.3. Segundas conclusiones intermedias; 5. Excurso: una solución transitoria; 6. Conclusiones finales

\section{EL PROBLEMA Y SU IMPORTANCIA}

La naturaleza dilemática del proceso penal, que se revela en su doble finalidad, inevitablemente conflictiva, de realizar el derecho penal sin menosprecio de los derechos fundamentales del imputado, ha sido considerada por ROXIN como el atractivo y la dificultad característicos del derecho procesal penal ${ }^{1}$. La manifestación más extensa —y también la más dramática- de este dilema se aprecia en la contradicción que aparentemente existe entre el sometimiento de una persona a enjuiciamiento penal y el reconocimiento de que goza del principio de inocencia, especialmente cuando se le aplican las medidas de coacción más intensas, que son las que afectan dicho principio hasta, en los hechos, neutralizarlo. Pero también por la sola realización del proceso, que es siempre coacción en sí mismo y que no puede ser pensado sin esa coacción, al menos en potencia como reaseguro de la efectiva producción de sus actos, los derechos individuales se ven menoscabados: "el simple inicio y tanto más el desarrollo del proceso penal causa sufrimiento: el sufrimiento del inocente es, desgraciadamente, el costo insuprimible del proceso penal'2.

Por ello, uno de los problemas más importantes al que se enfrenta el derecho procesal penal en la actualidad es el de la duración del enjuiciamiento, lo cual equivale a la duración de la neutralización del principio de inocencia que, como es evidente, debería ser breve, de modo que en el menor tiempo posible o bien el estado de inocencia, frente al hecho, quede consolidado definitivamente por la clausura del proceso a favor del imputado y terminen las molestias judiciales, o bien quede suprimido, también definitivamente, por la declaración firme de la necesidad y del deber de imponer una condenación al inculpado.

La situación descrita muestra las dos caras del problema de la excesiva duración del

\footnotetext{
* Artículo proporcionado por el autor y originalmente publicado en la Revista Jueces para la Democracia, Madrid, n. ${ }^{\circ} 49$ (2004).

${ }^{1}$ Roxin, Claus, Strafverfahrensrecht, Múnich, 251998, p. 4 (hay versión castellana de esa misma edición: Derecho Procesal Penal, trad. de Gabriela E. CóRDOBa y Daniel R. PASTOR, Buenos Aires, 2000, p. 4).

2 CARnelutTi, Francesco, Principi del processo penale, Napoli, 1960, p. 55.
} 
Pastor - Acerca del derecho fundamental al plazo razonable de duración del proceso penal

proceso penal. Por un lado, la prolongación del enjuiciamiento sin definición sobre la relación material que subyace a la acción perjudica los fines sustantivos del derecho objetivo, impide que la paz jurídica, jaqueada por la sospecha, se restablezca con la sentencia, sea absolutoria o condenatoria. Por el otro, también el derecho fundamental del imputado a ser juzgado tan rápidamente como sea posible es violado por la excesiva duración del proceso. Este trabajo sólo se ocupa de este segundo problema, a saber, del análisis dogmático de un derecho procesal subjetivo del inculpado ${ }^{3}$, el derecho fundamental a ser juzgado dentro de un plazo razonable. La cuestión de cómo acelerar la duración de los procesos no es tratada ni resuelta aquí, aunque, como se verá, la interpretación de ese derecho fundamental que este escrito defiende es también un instrumento que sirve a la vez para resolver ese problema en el caso individual y mejorar las condiciones de trabajo de la administración de justicia penal en general.

En la actualidad la excesiva duración del proceso penal es, sin duda, uno de los problemas cruciales del enjuiciamiento penal. GUARNIERI, cuya afirmación puede ser trasladada sin esfuerzo a todas las Naciones de derecho codificado, señala que el principal y más grave de los problemas actuales de la administración de justicia en Italia, y que reúne a todos los demás, es el de la duración de los procesos, y lo es tanto que este autor, además de recordarnos la proverbial sentencia "justicia lenta, justicia negada", afirma que por este problema la justicia italiana no puede ser considerada digna de un país civilizado ${ }^{4}$.

El propio GUARNIERI brinda los siguientes datos de duración de los procesos penales en promedio en algunos países europeos: entre 9 y 13 meses en Italia, de 3,9 a 5,1 en Alemania, entre 7 y 9 en Francia. En Italia el 48\% de las personas privadas de su libertad son imputados en prisión preventiva a la espera de juicio. La situación es similar en casi todos los países ${ }^{5}$. La afectación del principio de inocencia es evidente.

Esta disfunción de los sistemas judiciales por el retraso en la conclusión de los procesos pone en crisis toda legitimación y todos los postulados del derecho procesal penal. En efecto, las graves restricciones de la libertad y todas las demás cargas y perjuicios que el proceso penal entraña para el inculpado - y que deben ser sufridas por él pues la ley impone a todo sospechoso el llamado deber de soportar el proceso 6 - no pueden ser mantenidas, sin lesionar de modo intolerable el principio de inocencia, cuando la duración del proceso sobrepasa el límite de lo razonable. Toda la estructura instrumental del proceso penal está pensada para actuar en términos relativamente rápidos y, si ello no se consigue la justificación de sus poderes de intervención en los derechos fundamentales, se deteriora y los daños que ocasiona se tornan irreparables. Ejemplo de esta patología es la prisión provisional, normalmente vista como una de las cuestiones más problemáticas del derecho procesal penal, aunque, en verdad, lo problemático no es la privación de libertad procesal, sino la duración del proceso que permite la existencia y la persistencia de la prisión preventiva. Si no hubiera proceso alguno cuya duración excediera los dos o tres meses, la prisión provisional sería, salvo para quien sufra ese tiempo de detención injustamente, un problema menor en comparación con su relevancia actual.

\footnotetext{
3 Weigend, Thomas, en Verhandlungen des 60. Deutschen Juristentages (Münster 1994), Múnich, 1994, Sección M (derecho penal), pp. 11 y ss.

${ }^{4}$ GUARNIERI, Carlo, ¿Cómo funciona la máquina judicial? El modelo italiano, trad. de Alejandro W. SLOKAR y Norberto F. Frontini, Buenos Aires, 2003, p. 163.

${ }^{5}$ Ibidem, pp. 128 y ss.

${ }^{6}$ Roxin, Imme, Die Rechtsfolgen schwerwiegender Recbtsstaatsverstöße in der Strafrechtspflege, Múnich, ${ }^{21995, ~ p . ~} 218$.
} 
REJ - Revista de Estudios de la Justicia - No 4 - Año 2004

Más allá de ello, decisivo es el daño que el proceso sin definición causa a quien es inocente, pero también a la realización adecuada del derecho cuando el imputado es culpable y, finalmente, al pleno respeto de los derechos fundamentales respecto de quien, aunque no se sabe si es culpable o inocente, se ve sometido a una "pena de proceso" excesiva, cuando no interminable.

Una dogmática adecuada del derecho fundamental de toda persona a ser juzgada dentro de un plazo razonable debería servir para solucionar estos relevantes problemas.

\section{LA EVOLUCIÓN DE LA CUESTIÓN Y SU REGULACIÓN POSITIVA}

La preocupación por la lentitud de la administración de justicia en general no es nueva y Occidente siempre ha percibido que los molinos de la justicia son los que trabajan más despacio?. Decía ALCALÁ y ZAMORA que "la excesiva duración de los litigios constituye uno de los mayores y más viejos males de la administración de justicia". Ya en la recopilación de JUSTINIANO se recoge una constitución en la que se toman medidas "a fin de que los litigios no se hagan casi interminables y excedan de la duración de la vida de los hombres". Las leyes romanas establecieron un plazo preciso para la duración del proceso penal, disponiendo CONSTANTINO que empezara a contarse con la litiscontestación y que fuera de un año; plazo que, en la época de JUSTINIANO, era de dos años ${ }^{10}$. En la Magna Charta Libertatum, de 1215 , el rey inglés se comprometía a no denegar ni retardar derecho y justicia ${ }^{11}$. En el mismo siglo, ALFONSO X, el sabio, mandaba, en consonancia con la fuente predominantemente romano-justinianea de sus Siete Partidas, que ningún juicio penal pudiera durar más de dos años ${ }^{12}$. En los tiempos modernos, el problema fue preocupación de la ciencia jurídico-penal desde sus primeras y embrionarias manifestaciones. BECCARIA, en 1764, afirmó que "el proceso mismo debe terminarse en el más breve tiempo posible", porque "cuanto más pronta y más cercana al delito cometido sea la pena, será más justa y útil; [...] más justa, porque ahorra al reo los inútiles y feroces tormentos de la incertidumbre, que crecen con el vigor de la imaginación y con el sentimiento de la propia debilidad; más justa, porque siendo una pena la privación de la libertad, no puede preceder a la sentencia"13. Medio siglo más tarde que BECCARIA sería FEUERBACH quien diría que "no tardar es una obligación de los jueces"14. También SHAKESPEARE, en el que es quizá su pasaje más célebre, puso en boca de Hamlet a

\footnotetext{
7 WEIGEND, op. et loc. cit.

8 AlCalá-Zamora y Castillo, Niceto, Estampas procesales de la literatura española, Buenos Aires, 1961, p. 62.

${ }^{9}$ Constitutio Properandum (C, III, I, 13, Proemio). Se trata de una regulación del año 530, tiempo del Consulado, en Constantinopla, de LAMPADIO y ORESTE. Sin embargo, la regla aparentemente provendría de una constitución más antigua que se remontaría a los tiempos del emperador AUGUSTO.

10 Mommsen, Theodor, Derecho penal romano, trad. de Pedro Dorado Montero, Bogotá, 1991, p. 308. Igualmente, en el proemio de la constitución Properandum se informa que la ley limita a dos años la duración de las causas penales.

11 "No venderemos, denegaremos ni retrasaremos a nadie su derecho ni la justicia" "to no one we will sell, to no one deny or delay right or justice", en la versión inglesa). La regla, si bien no llevaba número originalmente, lleva hoy el 40 (artículo o capítulo) en la mayoría de las ediciones y traducciones. Sigo aquí el texto de DARANAS PELÁEZ, Mariano, Las constituciones europeas, Madrid, 1979, t. I, p. 925.

12 Ley 7, título 29, partida 7: "otrosí mandamos que ningún pleyto criminal non pueda durar más de dos años".

13 BeCCARIA, Cesare, De los delitos y de las penas, trad. de Francisco Tomás y VAliente, Madrid, 1982, pp. 128 y

${ }^{14}$ Feuerbach, Anselm RitTer von, Die Hohe Würde des Richteramts (1817), en Kleine Schriften vermischten Inhalts, Nürnberg, 1833, p. 132.
} 
Pastor - Acerca del derecho fundamental al plazo razonable de duración del proceso penal

la lentitud de los tribunales entre las causas que pueden aniquilar a un hombre15.

Como resultado de estas ideas, el derecho constitucional de inspiración ilustrada consagró expresamente el derecho de la persona acusada de haber cometido un delito, a ser juzgada rápidamente. Una primera manifestación expresa está contenida en la Declaración de Derechos hecha por los representantes del buen pueblo de Virginia, en 1776, según la cual toda persona sometida a persecución penal tiene derecho a un juicio rápido ante un jurado imparcial (Sección 8.a). Este derecho pasó a la 6. ${ }^{a}$ Enmienda de la Constitución de los EE.UU.: "En todos los juicios penales el acusado gozará del derecho a un proceso rápido"16.

Pero una preocupación más intensa sobre el derecho fundamental a la pronta conclusión del proceso penal sólo tuvo ocasión de dar frutos después de la Segunda Guerra Mundial, en el marco de la actividad de los tratados internacionales de derechos humanos de esa época que pretenden, frente al horror de los Estados totalitarios nazi y fascista, afianzar el Estado constitucional de derecho y hacer realidad la pretensión de universalidad de los derechos fundamentales perseguida ya por la Declaración Francesa de los Derechos del Hombre y del Ciudadano de 1789. En efecto, a pesar de que, como ya fue mencionado, los lamentos son antiguos, el problema de la excesiva duración del proceso sólo fue objeto de una regulación jurídica positiva específica y decidida después de $1945^{17}$, cuando en los catálogos de los derechos fundamentales fueron incluidos, junto a las garantías básicas burguesas ya consolidadas, también unos derechos básicos, llamados de "segunda generación", tendentes a reconocer la transformación de las expectativas jurídicas de los individuos, derivada del desarrollo de nuevas formas de relación entre estos y el Estado ${ }^{18}$.

Así, si bien la Declaración Universal de los Derechos Humanos de 1948 (DUDH) no consideró entre ellos el derecho a un juicio rápido ${ }^{19}$, sí se ocupó expresamente de la cuestión, ese mismo año, la Declaración Americana de los Derechos y Deberes del Hombre, cuyo art. XXV establece que "todo individuo que haya sido privado de su libertad tiene derecho [...] a ser juzgado sin dilación injustificada"20.

El Convenio Europeo para la Protección de los Derechos Humanos y de las Libertades Fundamentales de $1950(\mathrm{CEDH})$ es el primero de estos tratados internacionales que establece este derecho bajo la fórmula más usual del plazo razonable: "toda persona tiene derecho a que su causa sea oída de manera equitativa, públicamente y en un plazo razonable por un tribunal independiente e imparcial, establecido por la ley, que decidirá sobre sus derechos y obligaciones de carácter civil,

\footnotetext{
15 Acto Tercero: "The law's delay".

16 En principio, la regla, producto de la llamada bill of rights conformada por las diez primeras Enmiendas sancionadas a partir de 1789, regía sólo para la jurisdicción federal, pero con la cláusula del debido proceso de la 14. ${ }^{a}$ Enmienda (1866) se la consideró aplicable a las jurisdicciones locales (vid. CorwIN, Eduard S., La Constitución de los Estados Unidos y su significado actual, Buenos Aires, 1987, pp. 371 y 520).

17 Maier, Julio, Derecho Procesal Penal, Buenos Aires, 1996, t. I, p. 529. Aunque allí el autor se refiere a la limitación temporal de la prisión preventiva, dicho derecho responde a la misma factura que el que ocupa el centro de este trabajo.

18 Cf. Fernández-Viagas bartolomé, Plácido, El derecho a un proceso sin dilaciones indebidas, Madrid, 1994, p. 17.

${ }^{19} \mathrm{El}$ art. 10 de la DUDH (adoptada y proclamada por la Asamblea General de las Naciones Unidas en 1948), que establece los derechos básicos del acusado y es fuente directa y prácticamente literal de los arts. 6.1 del CEDH y 8.1 de la CADH, no menciona todavía el derecho a ser juzgado en un plazo razonable.

${ }^{20}$ Esta norma continua: "o, de lo contrario, a ser puesto en libertad", con lo cual comienza la controversia acerca de la posibilidad de que los procesos puedan tener dilaciones injustificadas (o ir más allá de su plazo razonable) con tal de que el imputado no sufra tal prolongación privado de su libertad.
} 
REJ - Revista de Estudios de la Justicia - Nº 4 - Año 2004

o bien sobre el fundamento de toda acusación penal dirigida contra ésta" (art. 6.1)21.

Luego, en 1966, el Pacto Internacional de Derechos Civiles y Políticos de la ONU (PIDCP: en vigor desde 1976) reguló, también en dos oportunidades, este derecho básico del imputado. En primer lugar, en el art. 9.3, al referirse a los derechos de quien está privado de su libertad provisionalmente, se estableció que toda persona detenida "tendrá derecho a ser juzgada dentro de un plazo razonable"22. En segundo lugar, en el art. 14.3.c se recurrió a otra fórmula para regular el mismo derecho de la persona acusada: "ser ju§gada sin dilaciones indebidas".

La Convención Americana sobre Derechos Humanos (CADH), dada en San José de Costa Rica en 1968 y en vigor desde 1978, siguió textualmente en esta materia, como en casi todas, el modelo europeo. En efecto, en el art. 7.5 se establece que "toda persona detenida o retenida [...] tendrá derecho a ser juzgada dentro de un plazo razonable"23. A su vez, y con más precisión, el art. 8.1 dispone que "toda persona tiene derecho a ser oída, con las debidas garantías y dentro de un plazo razonable, por un juez o tribunal competente, independiente e imparcial, establecido con anterioridad por la ley, en la sustanciación de cualquier acusación penal formulada contra ella".

La Convención sobre los Derechos del Niño, de 1989 y en vigor desde 1990, preceptúa que a todo ser humano menor de edad sometido a proceso penal se le debe garantizar "que la causa será dirimida sin demora por una autoridad u órgano judicial competente" (art. 40.2.b.iii).

Por lo demás, cabe mencionar que son numerosos los órdenes constitucionales del derecho comparado que incluyen al juicio penal rápido expresamente entre los derechos de la persona sometida a persecución penal. Así, p. ej., la Constitución de Canadá establece que toda persona acusada de delito tiene derecho a ser juzgada dentro de un plazo razonable (art. 11.b); la Constitución de México prescribe plazos de entre cuatro meses y un año como máximos para la duración de los procesos penales (art. $20 \mathrm{VIII}$ ); según la Constitución de Japón el acusado tiene derecho a un juicio rápido y público ante un tribunal imparcial (art. 37); la Constitución de Portugal dispone que el acusado debe ser juzgado tan rápidamente como ello sea compatible con la salvaguarda del ejercicio de su defensa (art. 32.2); la Constitución española otorga a todas las personas el derecho a un proceso público sin dilaciones indebidas (art. 24.2); por último, según una reforma reciente, la Constitución italiana sostiene que la ley debe asegurar la duración razonable del proceso (art. 111).

Todas estas formulaciones remiten a una misma configuración del derecho fundamental en análisis y tienen los mismos alcances: el imputado goza de un derecho constitucional subjetivo ${ }^{24}$ según el cual su proceso debe finalizar definitivamente dentro de un plazo que asegure un enjuiciamiento expeditivo. Por ello, en principio, estas diversas fórmulas de regulación de un mismo derecho son indistintas: "por derecho a un proceso 'sin

\footnotetext{
${ }^{21} \mathrm{El}$ art. 5.3 del Convenio, al prescribir que toda persona tiene derecho a ser juzgada en un plazo razonable o a ser puesta en libertad durante el proceso, sirvió también a la confusión de una posible prolongación del juicio, más allá de lo razonable, con tal que el imputado viva la duración excesiva en libertad.

${ }^{22}$ La objeción que esta norma merece, como ya se adelantó, proviene del resto de la frase: "[...] o a ser puesta en libertad', con lo cual se da a entender literalmente que el proceso podría tener una duración irrazonable con tal de que el imputado no siga privado de su libertad preventivamente.

23 "[...] o a ser puesta en libertad, sin perjuicio de que continúe el proceso", frase que repite el problema de la posibilidad de una continuación irrazonable del proceso pero sólo si el imputado está en libertad.

24 Weigend, op. cit., p. 17; Gimeno Sendra, Vicente, et al., Derecho Procesal Penal, Madrid, 31999 , p. 97.
} 
Pastor - Acerca del derecho fundamental al plazo razonable de duración del proceso penal

dilaciones indebidas' no cabe entender concepto diferente al de que la causa sea oída 'dentro de un plazo razonable"' 25 . Sin embargo, este trabajo ha de ceñirse más estrechamente a la expresión que, de entre todas las que resultan equivalentes, tiene la mejor factura técnica, a saber, la que prescribe el derecho del acusado a ser juzgado dentro de un plazo razonable, pues ella, a pesar de una inevitable textura abierta propia de toda regulación de derechos fundamentales, brinda, al menos en parte, una precisión insuperable al establecer la idea de plazo, concepto determinado con toda exactitud por la metodología del derecho procesal penal. Por otra parte, la fórmula del plazo razonable es por sí sola, aunque no únicamente, derecho entre una mayoría de naciones que están emparentadas con una misma cultura jurídica, aunque algunas más lejanamente (así, p. ej. Latinoamérica y Europa [CEDH, 6.1 y CADH, 8.1, respectivamente]). Además, la fórmula citada también lleva la preferencia debido a que la opinión dominante que se ha impuesto en esta materia en el ámbito cultural citado ha sido desarrollada por el Tribunal Europeo de Derechos Humanos (TEDH) a partir de la regla del plazo razonable.

Este trabajo, entonces, está dedicado, en lo que sigue, al estudio dogmático del derecho fundamental del imputado a ser juzgado dentro de un plazo razonable, es decir, a describir el estado de la cuestión y a proponer una interpretación posible del significado, de los alcances y de las consecuencias jurídicas de ese derecho a ser juzgado dentro de un plazo razonable, sin perjuicio de que también se lo mencione como derecho al juicio rápido, a un proceso sin dilaciones indebidas, o, que, directamente, se haga referencia a su antónimo, la excesiva duración del proceso penal, pues esto último es lo que se quiere evitar, en cuanto perjudica al imputado, con el plazo razonable como derecho fundamental, sin perjuicio de que la situación afecte también el interés público en la realización del derecho sustantivo a través de procedimientos eficaces también temporalmente.

\section{LA SUERTE DEL DERECHO AL PLAZO RAZONABLE EN LA APLICACIÓN PRÁCTICA: LA OPINIÓN DOMINANTE}

En las interpretaciones jurisprudenciales la cuestión comenzó a reflejarse decididamente sólo entrados ya los años sesenta. En tal sentido, se debe considerar que en 1968 el TEDH comenzó su larga e interesante serie de sentencias sobre el punto ${ }^{26}$. En la República Federal de Alemania, la primera sentencia trascendente del Tribunal Supremo Federal (BGH = Bundesgerichsthof) sobre el problema de la excesiva duración del proceso penal data de 196627. En 1967 comienza a construirse, en el derecho casuístico de los EE.UU., la jurisprudencia sobre el punto, cuando la Corte Suprema federal reconoció que el derecho a un juicio rápido tiene rango constitucional. Dicha jurisprudencia comenzó en relación con la duración de la detención y luego (1970-72) se extendió a la duración del procedimiento $^{28}$. Incluso llevó a la sanción de una ley federal que, en verdad, no es más que

\footnotetext{
25 GIMENO SENDRA et al., op. cit., p. 99, quienes citan jurisprudencia coincidente del Tribunal Constitucional español: "por dilación indebida no se está diciendo cosa distinta de lo que dice el art. 6.1 de la Convención europea" (STC 5/1985, FJ5).

26 Más detenidamente considerada en PASTOR, Daniel R., El plazo razonable en el proceso del Estado de derecho, Buenos Aires, 2002, pp. 109 y ss.

27 BGHSt 21, pp. 81 y ss. Mas detalles sobre la jurisprudencia alemana en Roxin, Imme, op. cit., pp. 216 y ss.

28 Casos "Klopfer v. North Carolina", 386 US 213 (1967); "Dickey v. Florida", 398 US 30, 37-38 (1970);

"Barker v. Wingo", 407 US 514 (1972), entre otros. Más información al respecto en KamisAR, Yale, et al., Modern Criminal Procedure, St. Paul (Minn.), ${ }^{9} 1999$, pp. 1105 y ss.; y en VIVES ANTón, Tomás, El derecho a un proceso sin dilaciones indebidas, en idem, La reforma del proceso penal (II), Valencia, 1992, pp. 41 y ss.
} 
un régimen de límites temporales al encarcelamiento preventivo ${ }^{29}$. También en Argentina, en 1968, se inicia, con la sentencia "Mattei" de la Corte Suprema de Justicia de la Nación, una línea jurisprudencial que, sin alcanzar claridad ni precisión, implicó el reconocimiento de un derecho constitucional del inculpado a que su situación frente a la ley penal y la sociedad sea definida en el menor tiempo posible por la innegable restricción de derechos que supone estar sometido a persecución penal por el Estado ${ }^{30}$.

En esa época el TEDH sentó las bases de lo que es hasta hoy y de modo prácticamente universal la interpretación dominante acerca del significado jurídico de la expresión "plazo razonable", ya se trate del plazo razonable de la prisión preventiva o del proceso. Aquí sólo puedo resumir los rasgos característicos de esa opinión dominante, que se desglosa en la definición de lo que se entiende por plazo razonable y en la determinación de las consecuencias jurídicas aplicables en caso de que el plazo sea superado.

Dicha posición interpreta, ante todo, que el plazo razonable no es un plazo ("doctrina del no plazo") en el sentido procesal penal, es decir, no considera a dicha expresión como condición de tiempo, prevista en abstracto por la ley, dentro de la cual - $\mathrm{y}$ sólo dentro de la cual- debe ser realizado un acto procesal o un conjunto de ellos, sino como una indicación para que, una vez concluido el proceso, los jueces evalúen la duración que tuvo el caso para estimar, según una serie de criterios, si esa duración fue o no razonable y, en caso de que no lo haya sido, compensarla de alguna manera. Según la opinión dominante el plazo razonable no se mide en días, semanas, meses o años, sino que se trata de un concepto jurídico indeterminado que debe ser evaluado por los jueces caso a caso terminado el caso - para saber si la duración fue razonable o no lo fue, teniendo en cuenta la duración efectiva del proceso, la complejidad del asunto y la prueba, la gravedad del hecho imputado, la actitud del inculpado, la conducta de las autoridades encargadas de realizar el procedimiento y otras circunstancias relevantes.

Si ese examen afirma que la duración fue irrazonable, se pasa al ámbito de las consecuencias jurídicas y se repara la violación del derecho fundamental ("solución compensatoria") de acuerdo a las posibilidades y a los límites de la competencia del quien decide, de modo que los órganos del derecho internacional de los derechos humanos (el TEDH, la CIDH) mandan indemnizar los retrasos y los tribunales nacionales o bien recurren también a ello o bien, dentro de las posibilidades que le brindan las leyes, atenúan la pena, prescinden de ella, dejan en suspenso su ejecución, remiten a la gracia o al indulto e, incluso, recurren a la sanción de los funcionarios responsables de los retrasos, todo ello con base en que el proceso fue excesivamente prolongado. Sólo excepcionalmente se recurre a la clausura del procedimiento, pues lo normal es que el examen se realice cuando el proceso ya ha concluido.

Esta sigue siendo hasta hoy la posición del TEDH que, p. ej., recientemente ha condenado a España, en el caso González-Doria Durán de Quiroga (STEDH de 28.10.2003), por violar el derecho de toda persona a ser juzgada dentro de un plazo razonable. El caso había tenido una duración total desde su comienzo con la primera actuación ante el Juzgado de Instrucción hasta que finalizó con la decisión del TC de rechazar un recurso de amparo de catorce años, cuatro meses y cinco días ${ }^{31}$. El TEDH

29 Speedy Trial Act (18 United States Code 3161 [1974]).

30 Más noticias al respecto en PASTOR, op. cit., pp. 241 y ss.

31 El proceso se había iniciado, en 1985, contra el nombrado, abogado y experto en negocios inmobiliarios, y contra otra persona — que corrió la misma suerte y que llevó su caso también ante el TEDH con el mismo 
Pastor - Acerca del derecho fundamental al plazo razonable de duración del proceso penal

reiteró su jurisprudencia anterior y señaló que la evaluación de la razonabilidad de la duración del proceso debía ser realizada de manera global, según las circunstancias del caso, y teniendo en cuenta especialmente la complejidad de los hechos y el comportamiento del imputado y de las autoridades de la persecución penal. Si bien el Tribunal, por unanimidad, consideró que el caso importaba cierta complejidad (numerosos documentos a examinar, necesidad de peritaciones, una reforma procesal intermedia, etc.) concluyó que esa complejidad no explicaba una duración tan prolongada y que ella tampoco podía atribuirse exclusivamente al comportamiento del imputado, de modo que condenó a España por la violación del derecho del imputado a ser juzgado dentro de una plazo razonable a compensar el daño moral así causado al inculpado con la suma de 10.000 EUR.

Un aspecto altamente llamativo y constante de la jurisprudencia del TEDH puede ser visto, no sin asombro, en el hecho de que nunca, en los casos de condena a los Estados, estableció en qué momento el plazo había sido violado.

De Alemania provino la idea, inspirada en la jurisprudencia del TEDH, de que la violación al plazo razonable, en caso de ser comprobada, fuera compensada ya en el mismo proceso. En efecto, tras algunas vacilaciones iniciales ${ }^{32}$, se asentó la doctrina según la cual la infracción debía ser considerada en la determinación judicial de la pena, pues la excesiva duración del proceso, sufrida por el imputado que resultaba condenado, debe ser tomada como una consecuencia negativa proveniente del Estado y que sufre el imputado a consecuencia del hecho, de modo que disminuye con ello proporcionalmente el reproche de la culpabilidad. Para estos casos se propone, en la medida en que lo permitan los límites de la ley, compensar la violación del plazo razonable con la reducción de la pena, incluso al mínimo, o con la suspensión de su ejecución o hasta con su prescindencia ${ }^{33}$. Sin embargo, la jurisprudencia alemana sigue sosteniendo, aunque sin claridad ni precisión y con menos convicción todavía, que en casos excepcionales la solución debe ser el sobreseimiento del caso y no hace mucho tiempo Alemania resultó condenada por el TEDH por violar el precepto del plazo razonable, aunque en la sentencia condenatoria dictada contra el afectado se había tomado en cuenta la situación en el marco de la culpabilidad reprochable y la medición consecuente de la pena y a pesar de que el TEDH, naturalmente, había visto con agrado esta solución compensatoria de los tribunales nacionales ${ }^{34}$.

resultado- con motivo de una serie de falsificaciones y una estafa cometidas en 1980 en el marco de unos contratos inmobiliarios. La instrucción se extendió por más de cuatro años y al finalizar y pasar el caso a la etapa siguiente tuvo que ser reenviado a la anterior para su adaptación a las entonces nuevas disposiciones procesales de la LO 7/1988, que entretanto habían entrado en vigor. Tras un juicio con gran cantidad de vicisitudes, entre ellas reiterados planteos del acusado referidos a la violación de su derecho a ser juzgado sin dilaciones indebidas, sólo el 5.5.1997 la Audiencia Provincial de Madrid condenó al imputado como autor de un delito continuado de falsedad en documento público en concurso con un delito de estafa, a la pena de cuatro años de prisión y multa de diez meses, con cuota diaria de 2.000 pesetas. El 4.12 .1998 el Tribunal Supremo rechazó el recurso de casación del condenado y mencionó, en cuanto a las quejas por el retraso del proceso, que la duración excesiva se debía a la complejidad del caso y al comportamiento del inculpado, sin que ello pudiera ser considerado violatorio del derecho a un proceso equitativo dentro de un plazo razonable. El 13 de octubre de 1999 el Tribunal Constitucional rechazó el recurso de amparo del condenado y, en lo que la duración del proceso toca, repitió los argumentos del TS. El 15 de diciembre de 2000 al condenado le fue indultada la mitad de la pena privativa de libertad pendiente, según Real Decreto n. ${ }^{\circ} 2398$ del 1.12.2000.

32 Tratadas con todo detalle en SCHEFFLER, Uwe, Die überlange Dauer von Strafverfahren, Berlín, 1991, pp. 24 y ss. 33 SCHEFFLER, op. cit., pp. 46 y ss.

34 Caso "Metzger (Alemania)", sentencia de 31.5.2001. Esta solución del sobreseimiento del proceso ha sido considerada cuando, por las características del caso, la salida compensatoria se ha visto incompetente (así en el caso de procesos por hechos menores pero de duración exorbitante en los cuales, además todavía era necesaria mucha más duración irrazonable antes de ser alcanzada una sentencia que, en caso de ser condenatoria, permitiría la posible compensación de la violación de este derecho). 
También en España se acepta, por un lado, que la posible verificación de la violación de este derecho no se establece por el cumplimiento de un plazo, sino que ello se deduce de la evaluación global de la duración de un proceso terminado o que está terminándose, y que, por otro lado, la compensación de las dilaciones indebidas en la pena es la consecuencia jurídica de la violación ${ }^{35}$. Pero hasta allí llega el acuerdo, pues lo que no se ha establecido es quién compensa la violación. Algunos autores y cierta jurisprudencia del TS que los respalda ${ }^{36}$, se inclinan por la solución alemana de reparar la violación en el ámbito de la determinación judicial de la pena por compensación de la culpabilidad. Sin embargo, la mayoría del TS y el TC parecen inclinarse por no reconocer efectos judiciales a la violación y remitir la cuestión a la gracia o el indulto ${ }^{37}$. Como sea, se impone en España la tesis de la determinación abierta de la violación y la compensación como solución de las violaciones comprobadas.

En Italia, donde el problema es mayúsculo y ha llevado a considerar, como ya se dijo, que gracias a él la justicia italiana no es digna de un país civilizado ${ }^{38}$, el Gobierno se vio en la obligación de reaccionar ante las reiteradas condenas del TEDH y las intervenciones del Comité de Ministros del Consejo de Europa, en las que se llamó la atención a Italia por no haber satisfecho la obligación de obedecer las decisiones del Tribunal y del Comité de Ministros que habían señalado la violación por parte de Italia del art. 6 del CEDH por vía de la excesiva duración de los procedimientos judiciales e invitado a ese país a recurrir a nuevas medidas para evitar nuevas violaciones al Convenio. Ante ello, Italia, siguiendo el criterio del TEDH, en cuanto a la necesidad de compensar los daños causados por la violación de la regla del plazo razonable, se limitó a establecer por ley la obligación de reclamar esa compensación primero ante el Estado italiano, de modo de evitar por esta vía más condenaciones de Italia por parte del TEDH, al menos por violaciones a este derecho ${ }^{39}$. Sin embargo, ante lo modestas que han resultado esas compensaciones se sostiene que quien sufre la violación de ese derecho no pierde la condición de víctima ante el TEDH hasta tanto la infracción no haya sido completamente reparada, de modo que si la compensación abonada por el Estado Miembro es insuficiente, el afectado puede reclamar la condena del país a pagar la diferencia ante el Tribunal de Estrasburgo.

En conclusión, se debe afirmar que acerca de la opinión universalmente dominante en la materia es posible advertir, dicho resumidamente, dos criterios centrales:

1) El plazo razonable de duración del proceso penal no es un plazo en sentido procesal penal que debe ser previsto abstractamente por la ley, sino que se trata de una pauta interpretativa abierta para estimar si la duración total de un proceso ha sido o no razonable, para lo cual debe procederse caso a caso, una vez finalizado el proceso y globalmente, tomando en cuenta la complejidad del caso, la gravedad del hecho ${ }^{40}$, las dificultades probatorias, la actitud del imputado y el comportamiento de las autoridades encargadas de la

\footnotetext{
35 BaCigalupo, Enrique, Justicia penal y derechos fundamentales, Madrid-Barcelona, 2002, pp. 124 y ss.

36 Así BACIGALUPO, op. cit., p. 125.

37 Ver la información y crítica al respecto en BACIGALUPO, op. cit., pp. 125 y ss.

38 GUARNIERI, op. et loc. cit.

39 Ley n. ${ }^{\circ}$ 89, de 24.3.2001, de Previsión de una indemnización equitativa en caso de violación del plazo razonable de duración del proceso.

40 A partir de la STEDH del caso "Metzger", ya citado, se ha introducido de manera preocupante la idea de que la "gravedad de la culpabilidad" del imputado es también un factor a considerar. Esto parece ser una “devolución de gentilezas" a los tribunales nacionales que al aceptar la tesis compensatoria del TEDH la tradujeron en disminución del reproche de culpabilidad y, consecuentemente, en atenuación de la pena.
} 
Pastor - Acerca del derecho fundamental al plazo razonable de duración del proceso penal

persecución penal.

2) Comprobada la irrazonabilidad de la duración, la violación del derecho debe ser compensada desde el punto de vista material, penal o civil, o dar lugar a sanciones administrativas, penales o disciplinarias, y sólo en casos extremos se justifica el sobreseimiento.

\section{LA INTERPRETACIÓN DEL PLAZO RAZONABLE PROPUESTA EN ESTE TRABAJO}

\subsection{Introducción}

El propósito de este trabajo a partir de aquí, es proponer una interpretación del derecho fundamental del imputado al "plazo razonable de duración del proceso penal" que se ciña más estrictamente que la opinión dominante a los fundamentos axiológicos del principio del Estado constitucional de derecho y de la dogmática del derecho procesal penal que es su consecuencia. Ese significado dogmático de la regla tratada discrepa con los postulados de la opinión dominante, tanto en cuanto al modo de determinación del plazo (tipo del derecho fundamental o antecedente de la regla) como en cuanto a las consecuencias previstas por el orden jurídico para el caso de que él sea sobrepasado (garantía ante la violación del derecho fundamental). Si bien no me ocupo de brindar soluciones politico-criminales tendentes a evitar el problema real, conocido y extendido de la excesiva duración de los procesos penales, las posiciones que aquí son adoptadas contienen también en sí mismas el efecto colateral de provocar la aceleración de los procedimientos $\mathrm{o}$, por lo menos, de llevar a una reorganización y racionalización indispensables de los recursos de la administración de justicia penal y, con ello, obtener un mayor grado de efectividad, en un doble sentido: tanto en lo que se refiere a la eficacia en el respeto de los derechos fundamentales de las personas sometidas a proceso por el Estado, cuanto en relación — y en consecuencia de lo anterior- con la mayor efectividad en la realización de la ley penal.

En lo que se sigue trataré de justificar por qué, en primer lugar, el plazo razonable debe ser un plazo establecido por la ley (punto 4.2) y, después, por qué en caso de que el plazo se cumpla, el proceso debe ser concluido (punto 4.3).

\subsection{El carácter legal del plazo razonable}

Según CARRARA, "sería burlarse del pueblo el dictar preceptos de procedimiento dejando su observancia a gusto del juez. [...] Si el legislador dicta un procedimiento que pueda ser violado al arbitrio de los jueces, no hace una ley, sino que se limita a dar un consejo" ${ }^{11}$. Esta frase nos advierte ya de la mayor objeción que puede ser formulada contra la interpretación dominante: ni la determinación de la duración razonable del proceso ni la de las consecuencias por su infracción, pueden quedar libradas abiertamente a la voluntad de los tribunales, como lo pretende tal interpretación dominante. Muy por lo contrario, la primera conclusión que se puede extraer dogmáticamente de la garantía de todo imputado a ser juzgado con celeridad, es la necesidad de que los ordenamientos jurídicos secundarios (reglamentarios

41 Carrara, Francesco, Programa de Derecho Criminal, trad. de José J. Ortega Torres y Jorge Guerrero, Bogotá, 1956, t. II, p. 277. 
REJ - Revista de Estudios de la Justicia - Nº 4 - Año 2004

de los derechos fundamentales ${ }^{42}$ ) establezcan con precisión el plazo máximo de duración del proceso penal y las consecuencias jurídicas que resultarán de su incumplimiento. Sólo en caso de ausencia de esa regulación legal obligatoria tendrán los jueces que asumir un papel activo, con el fin de que la ausencia de norma secundaria no obstaculice la efectividad del derecho. Por tanto, el plazo razonable de duración del proceso penal deber ser fijado por la ley. A continuación desarrollo las razones que avalan lo afirmado.

\subsubsection{El argumento del mandato expreso del orden jurídico internacional}

Los tratados internacionales que establecen derechos fundamentales deben ser vistos como modelos para las regulaciones del derecho interno de los EE.MM., pues el derecho internacional de los derechos fundamentales ha dejado de lado la práctica tradicional de delegar en la voluntad soberana de los Estados el reconocimiento, a través del derecho constitucional, de los derechos convencionales, para establecer su respeto obligatorio y restrictivo de los márgenes de decisión de los Estados ${ }^{43}$. Así, la nómina de derechos procesales de los distintos tratados debe servir de marco para la redacción de normas procesales, claras y precisas, que den vida y protección (efectividad) a los derechos consagrados abstractamente en ellos. Los catálogos de derechos fundamentales sólo pueden contener principios cuyo desarrollo específico (reformulación adecuada) corresponde a la legislación. Por consiguiente, no se puede esperar que un tratado internacional de derechos humanos (o la constitución del Estado) vaya más allá del reconocimiento abstracto y general de un derecho determinado y lo regule en todos sus detalles. Esa tarea constituye el contenido de la obligación de los Estados que forman parte de los convenios. En el plano internacional, la función de los órganos de control de los tratados será confrontar las regulaciones nacionales de los derechos convencionales para determinar si satisfacen las pretensiones de un derecho fundamental (control de razonabilidad) o si son insuficientes para asegurar su vigencia plena (función de garantía de los derechos fundamentales).

Es por ello que usualmente los EE.MM. de los tratados internacionales de derechos humanos se comprometen a adoptar, con arreglo a sus procedimientos constitucionales, las medidas necesarias para hacer efectivos los derechos y libertades reconocidos en dichos convenios ${ }^{44}$. En nuestra materia, esto significa que los Estados están obligados a regular por ley los plazos de duración de los procesos penales para brindar efectividad al derecho de todo imputado a ser juzgado dentro de un plazo razonable.

Por tanto, los inventarios de derechos fundamentales, sean internacionales o nacionales, deben ser entendidos, en cuanto a la regulación del plazo razonable, como órdenes para la adecuación de la legislación y la práctica con el fin de lograr una efectiva protección de los derechos en cuestión. En torno a ello no hay discrecionalidad para que

${ }^{42}$ Cf. MAIER, DPP, cit., t. I, pp. 162 y ss.; Roxin, Strafverfabrensrecht, cit., p. 9.

43 Pinto, Mónica, Temas de Derechos Humanos, Buenos Aires, 1997, p. 63.

${ }^{44}$ Así, p. ej., art. 2.2. del PIDCP y art. 2. ${ }^{\circ}$ de la CADH. La Corte Interamericana de Derechos Humanos ha dicho, al respecto, que pertenecer a la Convención "implica el deber de los Estados Parte de organizar todo el aparato gubernamental y, en general, todas las estructuras a través de las cuales se manifiesta el ejercicio del poder público, de manera tal que sean capaces de asegurar jurídicamente el libre y pleno ejercicio de los derechos bumanos" (Caso "Velásquez Rodríguez", sentencia de 29.7.1988). En el caso "Metzger", ya citado, en el cual el 31.5.2001 Alemania resultó condenada por violar el derecho al plazo razonable, el TEDH, en el FJ 42, señaló que "los EE.MM. están obligados a organizar su sistema de justicia de una manera que permita a los tribunales de las instancias inferiores y superiores estar en condiciones de cumplir con todas las exigencias necesarias para terminar con los procesos dentro de plazos razonables". 
Pastor - Acerca del derecho fundamental al plazo razonable de duración del proceso penal

el Estado decida la forma de satisfacer esta exigencia, ya que si bien ello puede ser adecuado en general, no resulta así cuando se trata, precisamente, de limitar la potestad de los jueces, pues permitirle a ellos, y no al legislador, establecer los límites (también temporales) de sus poderes sería tan ingenuo como pedirle al lobo, y no al pastor, que cuide las ovejas.

Por ello, no bien fue establecido internacionalmente el derecho del imputado a que su proceso se realice dentro de un plazo razonable se vio en ello, ante todo, un mensaje claro destinado al legislador, fundado en lo antedicho y en la necesaria vaguedad de la norma en cuestión. Así fue que, en 1953, Hellmuth von WEBER, en sus comentarios al CEDH afirmaba que "el proceso debe ser rápido, esto es, debe ser realizado dentro de un plazo razonable (within a reasonable time). Esta formulación deja un amplio campo de actuación a la discrecionalidady, por ello, no será fácil, en el caso concreto, demostrar la lesión de esta obligación (...) La ratificación del Convenio tiene que ser, por ello, un estímulo, más bien dirigido al legislador, para la reforma del proceso penal y, no necesariamente en última instancia, también con referencia a la aceleración del proceso" 45 .

Este razonamiento conduce, de modo inexorable, a justificar la afirmación de que es obligación internacional de los Estados fijar legislativamente un plazo máximo de duración de los procesos penales y las consecuencias jurídicas de su violación. La ley debe individualizar las herramientas para el cumplimiento de esta obligación omnipresente que es la de asegurar del modo más eficaz posible el respeto de los derechos fundamentales. Así, la reglamentación por ley es la única forma de dar plena satisfacción al derecho en análisis, que persigue limitar la arbitrariedad del Estado en cuanto a la duración del procedimiento, que trata de evitar que las consecuencias negativas del proceso se extiendan indefinidamente y que intenta, en fin, impedir que el instrumental extremadamente cargoso del proceso penal sea utilizado contra los ciudadanos en infracción grave y prolongada del principio de inocencia.

El derecho internacional de los derechos fundamentales requiere que los Estados contratantes de sus pactos establezcan en sus legislaciones plazos máximos de duración del proceso penal con aplicación de consecuencias para el caso de violación, de forma tal que éstas aseguren la existencia de aquéllos. La ausencia de una regulación específica de la duración del plazo razonable, cometida por un país signatario del tratado, debería conducir ya directamente a que él sea sancionado por la omisión de reglamentar - y con ello tornar ilusorio—el derecho analizado.

Llama la atención, por otra parte, que a pesar de que el TEDH ha desarrollado su doctrina del "no plazo" también para el plazo razonable de duración de la prisión provisional previsto con matices por el CEDH (igualmente por la CADH) los EE.MM. hayan entendido, sin embargo, que era necesario establecer por ley ese plazo, cosa que hicieron, y no así, todavía, el plazo razonable de duración del proceso ${ }^{46}$.

\footnotetext{
45 WEBER, Hellmuth von, Die strafrechtliche Bedeutung der europäschen Menschenrechtskonvention, en ZStW 65 (1953), p. 339.

46 Aunque cierta legislación provincial argentina y la de algunos países de Latinoamérica ya han establecido por ley plazos para la duración de los procesos todavía no es posible conocer completamente la suerte que han corrido esas reglas y si la idea de la necesidad de regulación legal no se consolida dogmáticamente se corre el riesgo de que en la aplicación práctica, siempre tan inclinada a ver los plazos que limitan el poder de la Fiscalía o del juez como meros consejos (doctrina de los plazos "ordenatorios"), se pierda el carácter fatal y perentorio que debe tener el plazo máximo de duración razonable del enjuiciamiento penal.
} 
La legislación de muchos EE.MM. de los distintos tratados (CEDH, PIDCP, $\mathrm{CADH})$, por tanto, está en falta frente a esos instrumentos internacionales, por cuanto no han dictado las leyes necesarias para dar plena eficacia al derecho al juicio rápido.

\subsubsection{El argumento del mandato expreso del principio del Estado de derecho}

El principio del Estado constitucional de derecho reclama que toda la actividad estatal esté regulada (autorizada, pero por ello también limitada) por la ley. El ejercicio del poder estatal, lo cual incluye muy especialmente a las decisiones de la Judicatura, siempre debe tener un fundamento legal que representa a la vez el respeto por la preeminencia del derecho pero también por el principio democrático ${ }^{47}$. La regla de derecho, como instrumento limitador del poder del Estado ${ }^{48}$, es ante todo un imperativo para lograr el mayor campo de libertad para las personas (seguridad), en tanto que les garantiza que sólo deberán omitir (o ejecutar) aquellas acciones que están prohibidas (o mandadas) ${ }^{49}$. La otra cara de la medalla de este principio es la prohibición para el Estado de realizar aquellas actividades que no le están expresamente autorizadas. En este sentido, una de esas actividades, sin duda la de mayor peligro para los derechos individuales, es el ejercicio del poder penal que monopólicamente ostenta el Estado, el cual no puede ser llevado a cabo sin previa autorización legal y dentro de los límites de esa autorización ${ }^{50}$.

El proceso penal en su conjunto afecta derechos del imputado por su mera realización, aun cuando no se dispongan medidas concretas de coacción. Es sabido que al ciudadano sometido a investigación penal se le exige tolerar el proceso y cumplir ciertos deberes que le son atribuidos bajo la amenaza de ejecución coactiva. Esto constituye una clara intervención en los derechos o libertades del imputado y sobre los límites temporales de esa intervención también debe decidir el Parlamento, pues la Constitución ha delegado en el legislador y no en los jueces la determinación precisa de las medidas que limitan los derechos individuales ${ }^{51}$. Se trata del principio de reserva legal regulado por el derecho público $^{52}$, pero de extraordinaria importancia para el orden jurídico-penal ${ }^{53}$.

A su vez, el sistema político del Estado de derecho exige que las reglas que restringen la actuación penal del Estado sean también establecidas por el legislador de forma tal que los derechos fundamentales tengan una vida práctica y efectiva. "Todos los

\footnotetext{
${ }^{47}$ Cf. Maunz, Theodor/Zippelius, Reinhold, Deutsches Staatsrecht, Múnich, 301998, p. 95.

${ }^{4}$ Ferrajoli, Luigi, Derecho y Råón, trad. de Perfecto ANDrÉs IbÁÑEZ et al., Madrid, 52001, p. 104, explica que por Estado de derecho se entiende "un tipo de ordenamiento en que el poder público, y específicamente el penal, está rígidamente limitado y vinculado a la ley en el plano sustancial (o de los contenidos penalmente relevantes) y bajo el procesal (o de las formas procesalmente vinculantes)". Para MAIER, DPP, cit., t. I, p. 90, "la limitación de los poderes del Estado es la nota característica del Estado de derecho".

49 "Todo lo que no es probibido por la ley no puede ser impedido y nadie puede ser obligado a hacer lo que ésta no ordena" (Declaración de los Derechos del Hombre y del Ciudadano de 1789, art. 5). Según FerRajoli (Derecho y Rąón, cit., pp. 34 y ss., y 71 y s.) este nexo entre libertad y legalidad, esta concepción de la libertad civil como libertad negativa garantizada por las leyes, es uno de los elementos fundamentales de la estructura del Estado de derecho y rasgo distintivo de toda la tradición jurídica ilustrada y liberal (vid. también en FERRAJOLI [ibid., p. 71, n. 5] la transcripción sucinta del principio según fuera expuesto en cada uno de los autores clásicos de la Ilustración).

50 Principio de reserva de la ley.

51 Así como también su contenido, vid. MAunz/Zippelius, op. cit., p. 150.

52 KLeinkneCht, Theodor/Meyer, Karlheinz/ MEYER-GOSSNER, Lutz, Strafprozeßsordnung, Múnich, 431997, p. 8.

53 MAIER, DPP, cit., t. I, p. 204.
} 
Pastor - Acerca del derecho fundamental al plazo razonable de duración del proceso penal

principios limitadores del poder penal del Estado que contiene la Constitución [...] son desarrollados y reglamentados en los códigos de procedimientos penales y leyes orgánicas judiciales. Al menos, asi debe ser, por la supremacía constitucional que determina la vigencia de la ley"54. Los reaseguros de este principio son las prohibiciones de que la reglamentación legal menoscabe el derecho básico reglamentado 55 y la de dejar abierta (delegar) la posibilidad de restringir los derechos fundamentales. Si los derechos fundamentales deben ser reglamentados con más detalle y precisión, como "forma de traducir a la realidad cotidiana de la persecución penal la protección necesaria de los derechos fundamentales consagrados en la Constitución del Estado para quien es perseguido penalmente" 56 , es evidente que esta tarea corresponde al legislador.

En cuanto al problema de la excesiva duración del proceso penal, el esquema anteriormente expuesto determina que ni el límite máximo de prolongación de un proceso (plazo razonable) ni las consecuencias jurídicas de sobrepasarlo pueden ser definidos por la ley de un modo abierto ni dejados a la determinación de los jueces (teoría del concepto jurídico indeterminado), sino que deben ser establecidos por el Parlamento para que realmente rija en toda su extensión el principio político según el cual toda la actividad del Estado, pero especialmente la que entraña el ejercicio de su violencia punitiva, tenga su legitimación en la ley y encuentre en ella también sus límites, incluso temporales.

En el régimen procesal penal de un Estado de derecho la ley es la única fuente de sus normas ${ }^{57}$. Así pues, el plazo razonable debe ser fijado por la ley y no por los tribunales, ya que para el orden jurídico-político de un Estado constitucional de derecho resulta inaceptable el derecho judicial e incluso penalmente desaprobado en el caso de decisiones contra legem (delito de prevaricación).

\subsubsection{El argumento del principio nulla coactio sine lege}

La coacción estatal punitiva, en tanto que intervención y menoscabo de derechos y libertades fundamentales reconocidos por el orden jurídico, se ejerce, principalmente, a través de la pena, pero también el proceso penal es, por definición, coerción estatal ${ }^{58}$. Los instrumentos particulares para el ejercicio de esta coacción procesal son diversos y bien conocidos. La característica común a todas estas intervenciones procesales en la esfera de derechos básicos de los individuos es la necesidad de que tales actividades procesales estén previamente establecidas y reguladas por la ley en toda su extensión y con toda precisión. Esta exigencia se conoce, para distinguirla del uso más extendido de la expresión legalidad procesal, como principio nulla coactio sine lege ${ }^{59}$. Esta coacción, que existe sólo por mandato legal, no se restringe a la prisión preventiva o a otros actos de idéntica energía de afectación de derechos. Por lo contrario, ella está presente en todos los actos del procedimiento, con lo cual toda la ley procesal penal debe quedar bajo la vigencia del principio nulla coactio y sus repercusiones jurídicas. La libertad del imputado se ve ya afectada con la mera realización del proceso en virtud del cúmulo de obligaciones que ello representa para él y de la posibilidad de ejecución coactiva que pende sobre cada

\footnotetext{
54 Ibidem, t. I, pp. 91 y 162 y ss.

55 Intangibilidad o inalterabilidad del contenido esencial del derecho fundamental.

${ }^{56}$ MAIER, DPP, cit., t. I, p. 164.

${ }^{57}$ Ibidem, t. I, pp. 120 y ss., y 193 y ss.

${ }^{58} \mathrm{Ibidem}$, t. I, p. 511.

59 Así llamado por Eberhard SCHмIDT, Zur Lehre von den strafprozessualen Zwangsmaßnahmen, en NJW 1962, p. 665.
} 
incumplimiento ${ }^{60}$.

Carece de todo sentido suponer que las distintas medidas del procedimiento y cada una de ellas deben estar regidas por el principio nulla coactio y no extraer, también, la misma conclusión para el proceso en su conjunto, ya que la existencia del proceso es presupuesto de cada una de sus medidas y si éstas requieren la fijación por ley de sus alcances y requisitos, entonces también los alcances del proceso en su totalidad deben estar fijados legislativamente. Las medidas concretas de coerción suponen, como presupuesto de validez, el ser tomadas en un proceso dado, el cual, a su vez, debe estar íntegramente predeterminado por la ley, de ahí que se lo llame proceso legal o "debido proceso legal". Esta legalidad, legismo o legitimidad del proceso ${ }^{61}$ abarca también los límites temporales de su validez. De este modo se afirma una relación recíprocamente dialéctica entre pena, proceso y medida de coacción procesal, según la cual un término supone al siguiente y todos deben estar determinados legislativamente con los alcances propios de los principios nulla poena, nullum crimen y nulla coactio: no hay coerción sin proceso fijado por la ley y no hay proceso sin ley que predetermine el hecho como delito y establezca la pena. Cada paso del procedimiento carece de sentido si no es contemplado con la imagen o la amenaza de la coacción pública detrás de él. Por tanto, si el proceso en sí es un acto de coerción o bien un conjunto de actos de coacción o de actos cuya realización es asegurada por medidas de coerción, que siempre intervienen en los derechos fundamentales de las personas, entonces su duración misma debe estar establecida por la ley con precisión.

El poder penal del Estado se manifiesta en tres actividades distintas ${ }^{62}$. La primera de ella consiste en la potestad de limitar de un modo vigoroso la libertad de las personas a través de las prohibiciones y mandatos penales. De esta forma, los individuos son constreñidos a no realizar determinadas acciones o a no omitir las acciones dispuestas como obligatorias. La legitimación democrática y constitucional de estas restricciones de la libertad proviene de la necesidad de que estén establecidas por el Parlamento y mediante leyes generales previas y claras. A su vez, en segundo lugar, también las penas que sufrirán compulsivamente los infractores son sólo admisibles, en tanto estén fijadas en la ley con toda precisión. En tercer término, la persona sospechosa de haber realizado una de esas conductas penalmente prohibidas es obligada a soportar el juicio previsto por la ley para determinar si realmente ha cometido alguna de esas conductas y, en ese caso, aplicarle alguna de las reacciones jurídicas predeterminadas por la ley. En esto último, como contracara del principio de legalidad procesal (obligatoriedad), corresponde al imputado la obligación de tolerar las investigaciones penales ${ }^{63}$. Estas tres actividades del Estado, a saber, prohibir, juggar y castigar, en tanto obligatorias para las personas que las sufren, esto es, restrictivas de la libertad individual, deben estar claramente previstas por la ley ${ }^{64}$ (principio de reserva).

No es necesaria una exposición detallada para explicar la forma en que el proceso menoscaba la libertad personal del imputado. Lo decisivo es, en primer lugar, la necesaria

\footnotetext{
${ }^{60}$ La Corte Suprema argentina ha reconocido no sólo esta afirmación, sino también su carácter autoevidente, al declarar, ya en 1968 y precisamente en un caso sobre duración del proceso, que el enjuiciamiento penal comporta una innegable restricción de la libertad del imputado (CSJN, Fallos, t. 272, pp. 188 y ss.).

${ }^{61}$ En palabras de MAIER, DPP, cit., t. I, pp. 91 y 121.

62 Vid., más detalladamente al respecto, FERRAjOLI, Derecho y Rąón, cit., pp. 34 y ss., y 71 y s.

${ }^{63}$ Roxin, Imme, op. cit., p. 147.

${ }^{64}$ FerRajoli, Derecho y Razón, op. et loc. cit.
} 
Pastor - Acerca del derecho fundamental al plazo razonable de duración del proceso penal

disposición del sospechoso a cumplir con los deberes que le genera el proceso, algo que ya muestra, como contrapartida, una severa restricción de la libertad, dado que esas obligaciones procesales no son, como es sabido, de cumplimiento voluntario. Además de esta restricción de libertad, de intensidad variable ${ }^{65}$ pero siempre existente, se debe considerar, en segundo término, a los restantes menoscabos que produce el proceso penal en los derechos fundamentales del imputado y que fundamentan la necesidad jurídica de que todo el proceso, incluidos sus límites temporales, esté fijado por la ley de modo tal que la autorización jurídica que recibe el Estado para usar su poder penal, quede perfectamente enmarcada, para que así se pueda distinguir con seguridad los momentos en que es legítimo o ilegítimo su ejercicio, siempre restrictivo de derechos fundamentales.

Es por ello, que la vigencia efectiva del principio constitucional del nulla coactio sine lege requiere que la duración máxima posible de la intervención del Estado en los derechos individuales a través del proceso penal (el plazo razonable) esté regulada por la ley previamente y con toda precisión.

\subsubsection{El argumento del principio de legalidad material}

La exigencia del orden jurídico de que deban ser regulados por la ley todos los alcances de la intervención en los derechos fundamentales que supone el proceso, se impone también por el reconocimiento del carácter similar a la pena del derecho material que éste tiene. En efecto, más allá de los fines, naturalmente formales, que la ley le atribuye al proceso penal, en los hechos él suele cumplir inevitablamente otros, de tipo material. Las reflexiones integrales más modernas que se han ocupado del funcionamiento del sistema penal y de precisar sus fundamentos axiológicos ${ }^{66}$, han demostrado con lucidez que la persecución penal estatal representa ya, con prisión provisional o sin ella, una "pena" por la sospecha: la "pena de proceso". En efecto, sobre todo en los procesos prolongados la persecución implica, desde el comienzo, el sometimiento del imputado a condiciones de "semi-penalización", que se manifiestan en ciertos padecimientos que encuadran en el llamado carácter idéntico a la pena que se atribuye ya al proceso: angustia, gastos, estigmatización, pérdida de tiempo y de trabajo, humillación, descrédito, etc. ${ }^{67}$. La falta de una determinación aproximadamente precisa de la duración del proceso, coloca al enjuiciado en la llamada "situación de doble incertidumbre": no sabe cómo terminará su proceso y tampoco sabe cuándo. A estas cargas hay que sumar, cuando el imputado está en prisión provisional, la directa anticipación de la pena de encierro, sin juicio y sin prueba públicos que certifiquen con certeza su culpabilidad y la necesidad de sufrir una pena privativa de libertad. Su situación de hecho es la de "ya-estar-penado" (Schon-bestraft-Sein) de la literatura alemana ${ }^{68}$.

\footnotetext{
${ }^{65}$ Ello depende, en gran medida, de las circunstancias del caso, pero también de la propia actitud del afectado, ya que si no asume las restricciones impuestas a su libertad es obligado a asumirlas con más privación de libertad.

${ }^{66}$ Así, p. ej., Ferrajoli, Derecho y Razón, cit., passim.

67 Según Kohlmann, Günter, "ÜberlangeStrafverfharen" — bekannt, bedenklich, aber nicht zu vermeiden?, en FSPfeiffer, Colonia, etc., 1988, p. 205, erradicar la sospecha que dio origen al procedimiento penal y a la exposición pública del imputado, sobre todo cuando el proceso alcanzó ciertos estadios (procesamiento, acusación, juicio), es imposible, al menos en la consideración social y en sus efectos colaterales, cualquiera que sea el grado de prueba de la inocencia; como máximo uno puede conseguir una prueba burocrática (documental) que lo certifique como inocente frente a la autoridad estatal. Por supuesto, todas estas "desgracias" que acarrea el proceso penal son transmitidas, casi directamente, a las personas cercanas al imputado, como sucede con la pena, cuyo carácter infamante sólo jurídicamente no es transmisible.

${ }^{68} \mathrm{Vid}$. al respecto, por todos, SCHEFFLER, op. cit., pp. 230 y ss.
} 
Pues bien, si resulta así innegable que el proceso como tal constituye, desde un punto de vista no sólo jurídico, sino también psicológico, sociológico y hasta ontológico, una especie de pena, entonces es también indiscutible que su medida, esto es, su duración, debe estar predeterminada con certeza por la ley, igual que cualquier otra pena (principio de legalidad). Tanto como nadie - bajo el imperio de un verdadero Estado de derechoaceptaría, por su flagrante choque con los principios constitucionales, que una pena tuviera una duración indeterminada, tampoco debe ser tolerada una pena de proceso de duración indefinida ${ }^{69}$.

Por lo tanto, la duración precisa del proceso, en cuanto "pena", debe ser determinada por la ley como cualquier otra pena (principio nulla poena sine lege).

\subsubsection{El argumento de la división de poderes}

La opinión dominante en materia de plazo razonable, en cuanto delega en los jueces la determinación de su extensión y consecuencias, viola también el principio de la división de poderes de modo evidente y según ya se ha insinuado precedentemente, toda vez que las reglas del procedimiento deben ser fijadas por el legislador y no por el Poder Judicial. Aquí está en juego el principio democrático mismo, perjudicado irremediablemente en tanto se permita que una decisión trascendente sobre la afectación de los derechos más importantes de los individuos, cual es el límite temporal de la persecución penal, sea tomada por autoridades estatales que no representan tan intensamente como el Parlamento al conjunto de los ciudadanos. La reserva en el Poder Legislativo de la facultad de dictar estas limitaciones de los derechos básicos, en nuestro caso los alcances del deber de los habitantes de estar sometidos a las "molestias y tormentos" del proceso penal, asegura que esas limitaciones serán discutidas y decididas a través de un proceso más transparente que la deliberación judicial, con participación de la oposición y también con amplias posibilidades de intervención de los afectados ${ }^{70}$. Ello se debe a que, en el sistema constitucional de derecho, los actos de los poderes no parlamentarios (Administración y Judicatura) sólo pueden encontrar en la ley su legitimación democrática. Según el sistema jurídico, "las reglas creadas formalmente por el legislador (parlamento representativo), de conformidad con las leyes fundamentales del Estado (constitución escrita), son las unicas que, en principio, permiten fundar correctamente tanto la actuación de los organismos predispuestos para la aplicación de la ley, en caso de conflicto, como la solución de esos conflictos, sean ellos materiales of formales" 71 .

Por ello, se debe afirmar que también el principio de la división de poderes, cuya aparición histórica con el triunfo de la ilustración tuvo una importancia decisiva en la configuración del proceso penal actual ${ }^{72}$, impone que la reglamentación del plazo razonable sea llevada a cabo por vía legislativa para que de ese modo rija eficazmente una verdadera reserva de la ley, de modo tal "que la intervención del Estado en la esfera de libertad del imputado sólo pueda ser llevada a cabo de acuerdo a la decisión de las leyes, las que deben establecer los presupuestos, contenidos y límites de aquélla del modo más preciso posible, para que, de esa forma, las

\footnotetext{
${ }^{69} \mathrm{Si}$ el proceso prolongado es nocivo, su situación no debería ser distinta, p. ej., a la del trabajo insalubre, que es tolerado pero limitado por la ley a unos tiempos máximos permitidos.

${ }^{70}$ Así en las sentencias del Tribunal Constitucional Federal alemán en BVerfGE 40, pp. 248 y ss.; 49, pp. 126 y ss.; 95, pp. 307 y s.; vid. también MAunZ/Zippelius, op. cit., p. 95.

${ }^{71}$ MAIER, DPP, cit., t. I, p. 193.

72 Roxin, Strafverfahrensrecht, cit., p. 10.
} 
Pastor - Acerca del derecho fundamental al plazo razonable de duración del proceso penal

medidas estatales sean previsibles para los ciudadanos"73.

\subsubsection{Primeras conclusiones intermedias}

Hasta aquí creo haber justificado dogmáticamente la necesidad de que la ley procesal penal establezca el plazo (o los plazos ${ }^{74}$ ) que considere razonable(s) para la duración del proceso. No puedo, en cambio, establecer aquí y ahora cuál es (o cuáles son) ese plazo (o esos plazos) que debe imponer el legislador. Esa tarea es ajena al método de este trabajo y depende de una investigación empírica de campo, acerca de las razones que provocan los retrasos del procedimiento y de un estudio del modo en que los distintos factores posibles (tipo de procedimiento, complejidad probatoria del hecho, dificultades en la aplicación del derecho al caso, cantidad de delitos, de imputados, de víctimas, etc.) deben ser combinados para establecer esos plazos.

\subsection{Las consecuencias jurídicas del cumplimiento del plazo razonable}

\subsubsection{El plazo razonable con los efectos de un plazo procesal}

Ante todo, se debe reconocer que el plazo razonable es un plazo entendido con el sentido que le asigna el derecho procesal penal a tal expresión, ya que de otro modo, esto es, con el criterio de la opinión dominante, no es posible cumplir con la finalidad de garantizar el derecho fundamental en cuestión, pues la regla que lo establece pretende la introducción de plazos al proceso y no otra cosa. Este derecho fundamental tiene una finalidad específica, precisa y clara: evitar que las personas sometidas a proceso penal sean efectivamente perseguidas más allá de un plazo cierto.

Por regla general, plazo es el espacio de tiempo dentro del cual debe ser realizado un acto procesal ${ }^{75}$. En efecto, plazo, para el derecho procesal penal, es toda condición de tiempo puesta al ejercicio de una determinada actividad procesal ${ }^{76}$. En relación con el plazo razonable esto quiere decir que todo el proceso, como conjunto máximo de la actividad procesal, debe (sólo puede) ser realizado dentro del tiempo fijado como razonable. Dicho de otra manera, el plazo razonable es aquel período únicamente dentro del cual puede ser llevado a cabo un proceso penal adecuado al Estado de derecho. Ese lapso es determinado de acuerdo a la normativización de la medición del tiempo que rige todos los aspectos de la vida cotidiana; así pues, normalmente, los plazos son establecidos en horas, días, semanas, meses y años.

El contraste entre aquello que el orden jurídico concibe como "plazos del proceso penal" y lo que percibe por "plazo del proceso penal", la opinión dominante en materia de juicio rápido no podría ser mayor. Así, mientras que para la opinión dominante en la materia, el plazo razonable del proceso penal no puede ser fijado en abstracto ni medido en días, semanas, meses o años, el orden jurídico, en cambio, no conoce ninguna otra forma de tratar

\footnotetext{
73 Ibidem.

${ }^{74} \mathrm{El}$ plazo legal máximo para la duración del proceso no tiene que ser necesariamente un plazo único.

75 Roxin, Strafverfahrensrecht, cit., p. 169. Los plazos de inactividad, como, p. ej., el plazo de suspensión de la vista oral, la audiencia de juicio o de debate ante la ampliación de la acusación, son una excepción en los ordenamientos procesales.

76 Manzini, Vincenzo, Tratado de Derecho Procesal Penal, trad. de Santiago Sentís Melendo y Mariano Ayerra REDín, Buenos Aires, 1954, t. III, p. 76.
} 
con plazos que no sea en abstracto ${ }^{77}$ y a través de esas unidades temporales. Obsérvese, por otra parte, que todos los Estados de derecho avanzados han entendido que la norma del derecho internacional de los derechos humanos, según la cual la prisión preventiva no puede sobrepasar un plazo razonable, era un mandato para limitarla a través de plazos legales; y así lo han hecho y los han establecido en meses o años según los casos.

Así pues, por "ser juzgado dentro de un plazo razonable" sólo se puede entender, con rigor dogmático, que el proceso penal debe tener un plazo máximo de duración establecido por la ley más allá del cual aquél no podrá seguir siendo llevado a cabo.

\subsubsection{El cumplimiento del plazo razonable como impedimento procesal}

El hecho de que un proceso haya alcanzado su plazo máximo de duración razonable debe ser tratado, técnicamente, como un impedimento procesal, que es el medio a través del cual se hace efectiva, en un procedimiento concreto, la consecuencia que se deriva de la violación de una regla de derecho limitadora del poder penal del Estado, con el fin de obstruir la continuación de un juicio que se ha tornado ilegítimo. Frente a esta infracción el proceso, no puede seguir adelante y debe ser concluido de un modo anticipado y definitivo. Una correcta comprensión de la función de garantía judicial de los derechos fundamentales que tienen las estructuras procesales, impone esa conclusión como la única adecuada a la situación. De ningún otro modo no arbitrario puede ser garantizado este derecho fundamental. Para ello, el sistema de los impedimentos procesales es el instrumento que mejor sirve para alcanzar este cometido, pues dichos obstáculos, como es sabido, están predispuestos para evitar la continuación del proceso, por razones ajenas al fondo del asunto, cuando está afectada su legitimidad. Son la contracara de los presupuestos procesales o condiciones de procedibilidad requeridos para que el proceso y la eventual condenación sean válidos.

Una vez establecido, como lo ha sido precedentemente, que el sistema de los impedimentos procesales es el remedio técnico que el derecho procesal penal brinda para tratar el problema de la excesiva duración del proceso penal, en cuanto violación de un derecho fundamental del acusado y en tanto que ese derecho indica que no es posible continuar con un procedimiento que ha superado su plazo máximo de duración razonable, dependerá de cada ordenamiento positivo concreto el saber cuál es el vehículo procesal previsto para tales situaciones, aunque normalmente se trata del sistema de las excepciones procesales, pues es el que está pensado por la dogmática del derecho procesal penal para que los impedimentos procesales puedan ser invocados y demostrados, con el fin de que rindan sus efectos.

Con este alcance, es el régimen procesal de las excepciones o artículos de previo pronunciamiento, el que normalmente brinda el instrumental procesal positivo adecuado para hacer valer el impedimento procesal de la excesiva duración del proceso penal en el caso concreto. Este sistema es ya, de modo regular, el previsto para el planteamiento efectivo de los demás supuestos de impedimentos procesales (falta de jurisdicción, falta de competencia, extinción de la acción o del delito, litis pendentia, cosa juzgada, etc.). Ello muestra que, de esta forma, excepciones e impedimentos procesales aparecen

\footnotetext{
${ }^{77}$ Los plazos judiciales o judicialmente determinables necesitan igualmente un marco legal previo y se limitan a cuestiones intrascendentes del proceso y no a la reglamentación de un derecho fundamental.
} 
Pastor - Acerca del derecho fundamental al plazo razonable de duración del proceso penal

confundidos $^{78}$ y que, conceptualmente, las excepciones son defensas formales, no materiales, frente a la imputación (de allí, precisamente, proviene el nombre con el que se las conoce). Por tanto, ellas permiten una solución puramente procesal del caso, tal como lo reclama en particular el problema del cumplimiento del plazo razonable de duración del proceso penal y en general todo obstáculo procesal, más allá de las consecuencias materiales ulteriores que necesariamente se desprendan de una sentencia procesal. Las excepciones o artículos de previo pronunciamiento son mecanismos de resistencia previstos para evitar, temporal o definitivamente, según el tipo de impedimento, el progreso de la imputación en su camino hacia la sentencia. Con independencia de que los hechos generadores de su utilización respondan a razones sustantivas (como la prescripción) o procesales (p. ej., la litis pendentia), la decisión que los acoge es siempre una resolución procesal ${ }^{79}$. Esto es también lo que justifica que el cumplimiento del plazo razonable de duración del proceso penal deba ser tratado como un impedimento procesal que da lugar al procedimiento previsto para las excepciones con el fin de obtener una declaración judicial formal sobre su existencia y admisibilidad.

Y aunque el impedimento procesal analizado no está dispuesto de modo expreso entre las excepciones mencionadas normalmente por las leyes de enjuiciamiento penal, pues precisamente el déficit de nuestros países en la materia es no tener normas efectivas sobre la duración máxima razonable del proceso, él resulta de todos modos abarcado por ellas, en tanto que dogmáticamente el régimen de las excepciones prevé unas conclusiones y un procedimiento para todo un elenco abierto de impedimentos procesales. Más allá de que las legislaciones concretas, en algunos casos, o las interpretaciones jurisprudenciales, en otros, afirmen que el catálogo de excepciones o artículos de previo pronunciamiento es cerrado (taxativo), lo cierto es que dicho régimen cumple una función al servicio del principio del Estado constitucional de derecho que está por encima de la legislación y su interpretación. En efecto, se trata de impedir que las graves vulneraciones del principio del Estado de derecho cometidas en un proceso judicial, que implican la descalificación del proceso como juicio justo o leal, queden sin consecuencias sólo porque la ley no menciona esa violación entre las excepciones previstas. Si esto fuera así debería conservar su valor un proceso ilegítimo. Muy por lo contrario, dado que los impedimentos muestran que el proceso ya no es válido, cada vez que ello ocurra, aunque la violación, por así decirlo, esté fuera de catálogo, de todos modos la cuestión operará como un impedimento procesal, aún cuando la ley no lo prevea, para evitar que un proceso ilegítimo siga adelante con la pretensión de resolver el fondo del asunto, cuando están ausentes presupuestos de forma más que básicos.

En tal sentido, ante el cumplimiento del plazo razonable de duración del proceso penal, si este derecho fundamental tiene algún sentido, éste no puede ser más que el de impedir el progreso ulterior del procedimiento a partir de ese instante, con lo cual, en los hechos y en derecho, el ejercicio de la acción ya no puede ser continuado.

En esta fundamentación representa un papel decisivo el argumento interpretativo del carácter abierto de los impedimentos procesales que habilitan su tratamiento,

\footnotetext{
78 De hecho, los vocablos impedimento y excepción pueden ser entendidos como sinónimos.

79 La decisión que estima un impedimento procesal (una excepción) será siempre procesal, aún en los supuestos en que se la dicte en función del reconocimiento de un hecho regulado por el derecho sustantivo, ya que el rasgo característico que permite esta calificación es que ella evita el tratamiento, prueba, discusión y resolución del fondo del asunto, contenido propio, por regla, de la sentencia definitiva y del sobreseimiento material.
} 
discusión y resolución por vía del procedimiento de las excepciones que están previstas necesariamente por el orden constitucional bajo un régimen de numerus apertus, más allá de lo que diga una legislación determinada, pues ellas sirven al aseguramiento del principio superior del Estado constitucional de derecho en procesos cuya realización vulnera dicho principio de un modo tan claro como intolerable. La consideración de cada impedimento en particular implicará también, de acuerdo a su naturaleza, su tipificación, p. ej., como obstáculo formal temporal o definitivo (en la terminología habitual excepciones dilatorias o perentorias) y también la asignación del procedimiento con el que corresponde que sea tratado. Por ello, en cuanto a nuestro problema, la fórmula que mejor conviene a la naturaleza del impedimento tratado, es la aplicación analógica de los preceptos referidos a la prescripción del hecho, en tanto que, aunque no sean lo mismo, algunos aspectos y sobre todo sus efectos, son similares. Con ello, también, se salva la objeción de la falta de regulación expresa de la cuestión como excepción o artículo de previo pronunciamiento, pues nadie debe dudar del acierto de presentar al cumplimiento del plazo razonable como interpretación analógica ${ }^{80}$ in bonam partem de la excepción de prescripción del delito.

Siguiendo este razonamiento, se puede ver con claridad que la solución compensatoria de la opinión dominante en materia de consecuencias por la verificación de la violación del derecho fundamental de las personas imputadas penalmente a ser juzgadas dentro de un plazo razonable resulta, a mi juicio, fundadamente objetable. Si bien los organismos internacionales creados por los tratados de derechos fundamentales para controlar su efectivo respeto en los EE.MM. no tienen más posibilidad en los casos concretos que la de imponer una reparación frente a las violaciones que comprueban, este criterio no es trasladable sin más a la Judicatura interna. Si, p. ej., el imputado ha sido engañado o coaccionado a confesar y ofrecer las pruebas de su hecho, en las cuales después el Estado basó su condenación firme, no hay duda alguna de que, llegado el caso a un órgano internacional de protección de los derechos fundamentales, el Estado será condenado a reparar la violación cometida, pero si ya antes, durante el proceso según el derecho interno, p. ej. al momento de la sentencia, las autoridades del caso comprueban la lesión a ese derecho fundamental, nadie aceptaría que la solución sea aprovechar las pruebas obtenidas ilícitamente, condenar al acusado y remitir la cuestión de la infracción de sus derechos fundamentales a la determinación judicial de la pena en orden a la compensación parcial del reproche de culpabilidad en virtud de la disminución que ésta ha tenido al ser ya "sufrimiento por el hecho" el que ha padecido el autor con motivo de la violación de su derecho subjetivo a no ser obligado a incriminarse a sí mismo. Pues bien, así pues, tampoco resulta aceptable que si el derecho violado es el del plazo razonable se pueda, sin más, reconocer tal violación e indicar que a lo sumo habrá que "descontarla" de la pena.

Por lo demás, la opinión dominante no brinda una solución adecuada a quien es declarado inocente en la sentencia (caso para el cual sólo quedará la compensación no penal) ni para el problema que representa el reconocimiento de la violación del plazo razonable cuando todavía la sentencia, en la que eventualmente habrá una compensación en la determinación de la pena, está a muchos años de distancia, pues no es jurídicamente apropiado establecer que se ha violado un derecho fundamental y que la consecuencia es que se va a seguir violando.

\subsubsection{Segundas conclusiones intermedias}

\footnotetext{
80 ¡Pero sólo analógica!
} 
Pastor - Acerca del derecho fundamental al plazo razonable de duración del proceso penal

Desde el punto de vista jurídico todos los derechos fundamentales de protección de las personas frente al poder penal del Estado tienen el mismo rango y los mismos efectos. Por tanto, si el que nadie pueda ser obligado a declarar contra sí mismo quiere decir que en ningún caso, de suceder, ello podrá ser válido y aprovechable para el proceso, entonces el que todo imputado tenga derecho a ser juzgado dentro de un plazo razonable quiere significar que, si se reconoce que se ha cumplido el plazo razonable, esa persona ya no puede ser juzgada.

\section{EXCURSO: UNA SOLUCIÓN TRANSITORIA}

Hasta tanto la ley regule el plazo razonable de duración del proceso es preciso encontrar una solución que dé efectividad a ese derecho fundamental por encima de la insuficientes fórmulas del "no plazo" y de la "solución compensatoria".

Normalmente y salvo algunas excepciones, la ley regula la duración máxima razonable de la prisión preventiva pero no la del proceso. Pero ¿qué relación hay entre prisión preventiva y proceso? Una primera aproximación a la respuesta indica que con la conformación actual de la pena estatal centralmente como privación de libertad resulta inconcebible un proceso penal sin prisión provisional ${ }^{81}$. Por lo tanto, mientras dure el proceso penal deberá perdurar también, entre sus instrumentos, la posibilidad de imponer la privación de libertad del imputado si fuera necesaria para asegurar sus fines. Esta idea, en sí indiscutible, implica que, o bien la prisión preventiva no está en verdad restringida en su duración a un plazo legal razonable, o bien que ese límite temporal es también, a la vez, el plazo máximo de duración razonable del proceso mismo. Para que esta afirmación y su funcionamiento jurídico-procesal puedan ser entendidos correctamente, es necesario distinguir todavía entre diversas categorías conceptuales.

Así, es preciso mencionar la distinción entre plazo de la prisión preventiva y plazo razonable de la prisión preventiva. Difícilmente alguna otra distinción podría ser más sencilla, pues el adjetivo razonable marca ya, tautológicamente, la diferencia. En términos de aplicación ello significa que el plazo legal de la prisión preventiva puede todavía no ser razonable, dado que el límite temporal fijado por el legislador como máximo para la duración de esa medida cautelar podría resultar irrazonable por ser extremadamente prolongado. Así, si hipotéticamente se estableciera que la razonabilidad está fijada en tres o cuatro años, todo plazo legal superior resultaría inadmisible. Consecuentemente, un lapso de seis meses, supuestamente previsto por la ley, no sería irrazonable. Problemático resulta qué debe pasar si liberado el imputado al cumplir un plazo de seis meses en prisión provisional, sin perjuicio de que continúe el proceso $(\mathrm{CADH}, 7.5)-\mathrm{O}$ habiendo sido puesto en libertad durante el procedimiento $(\mathrm{CEDH}, 5.3)-$, debe volver a ser privado de su libertad posteriormente porque lo exigen circunstancias del procedimiento. Esto sólo sería posible bajo tres condiciones. La primera, ya mencionada, es que el imputado haya sido liberado al cumplirse el plazo máximo para la prisión preventiva previsto por la ley (agotamiento del plazo formal), seis meses en el ejemplo. Según la segunda, el imputado debe haber dado lugar a la necesidad de detenerle nuevamente (estado voluntario de rebeldía

\footnotetext{
81 Convincentes al respecto son las argumentaciones de LLOBET RODRÍGUEZ, Javier, La prisión preventiva (límites constitucionales), San José de Costa Rica, 1997, pp. 37 y ss., 72 y ss., 164 y ss., y passim; autor que además brinda, con esmerado esfuerzo, una explicación aceptable para superar la incompatibilidad entre prisión preventiva y principio de inocencia.
} 
procesal). Y la tercera, que el tiempo de prisión preventiva no supere en total, contadas la primera y segunda detención, como también todas las demás posteriores, dado el caso, el límite de razonabilidad máximo (agotamiento del plazo material), fijado en tres o cuatro años en esta hipótesis de trabajo.

De este modo, el Estado puede fijar por ley el plazo de duración de la prisión preventiva por debajo del límite de razonabilidad y reservarse el "saldo" para aplicarlo a las posteriores detenciones del imputado que sean necesarias y sólo si son necesarias. Pero una vez cumplido el plazo formal, aun cuando sea inferior al razonable, el imputado debe ser liberado a pesar de que subsistan las razones que fundaron su prisión preventiva, debido a que, de lo contrario, ni siquiera se podría hablar de límite temporal de la prisión preventiva, toda vez que ello supone sine qua non la existencia de una prisión preventiva justificada en dichas razones. Después de ello, sólo podría volver a ser detenido en caso de que se sustraiga a una citación o a otra obligación de comparecer en el proceso y como máximo sólo hasta el agotamiento, en total, del plazo razonable (plazo material).

Así, el límite de razonabilidad de la prisión preventiva es, a la vez, el límite máximo de duración posible del proceso penal, toda vez que, alcanzado aquél, ya no puede ser renovada medida de coacción alguna contra la libertad del imputado y dado que sin ello el proceso no puede continuar más que voluntariamente, cosa que, como tal, es inconcebible. Por ello, es preciso que él cese definitivamente. Por razones de coherencia intrasistemática, sin cuyo respeto el derecho procesal penal no puede actuar de forma racional, se debe aceptar que el plazo máximo de duración tolerado por la prisión preventiva tiene que funcionar también, en principio y en ausencia de una regulación específica al respecto, como plazo razonable dentro del cual debe ser llevado a cabo el proceso penal en su totalidad, pues o también el proceso termina al extinguirse el plazo razonable de la prisión preventiva, o el proceso continúa y, entonces, no hay límite razonable de la prisión preventiva, ya que no se concibe al proceso sin prisión preventiva, latente o efectiva.

El plazo máximo de duración de la prisión provisional tiene además la ventaja de estar determinado por la ley $y$, por otra parte, al ser definido de este modo, es un indicador de lo que él ha pensado en abstracto no sólo como lapso de duración de esa medida de coacción específica, sino también, necesariamente en la inteligencia de lo dicho precedentemente, como plazo máximo de duración razonable de todo el proceso, con o sin aplicación de prisión preventiva, bajo una regla que diría a las autoridades de la persecución penal que disponen de tanto tiempo para terminar con el proceso como tengan para hacer durar una eventual prisión provisional.

\section{CONCLUSIONES FINALES}

Recapitulando, se debe decir que toda persona perseguida penalmente cuenta con un derecho fundamental a ser juzgada rápidamente, sin dilaciones injustificadas o indebidas, dentro de un plazo razonable. Esta prerrogativa es regla expresa del derecho internacional de los derechos humanos y también de algunas constituciones y leyes procesales secundarias. Sin embargo, la opinión dominante acerca de los alcances prácticos de este derecho fundamental no ha reconocido, como regla general, que él represente una limitación temporal precisa del poder penal estatal, tanto en cuanto a la forma de establecer la razonabilidad de la duración de los procesos como en cuanto a la 
Pastor - Acerca del derecho fundamental al plazo razonable de duración del proceso penal

consecuencia jurídica aplicable si dicha duración es sobrepasada.

En efecto, la opinión dominante ha entendido que, ante todo, el plazo razonable no es un plazo, sino una pauta genérica, un concepto jurídico indeterminado útil para evaluar, cuando el proceso penal ya ha concluido, si su duración ha sido razonable. Se ha hecho notar al respecto, entonces, que esta postura constituye, abiertamente, una doctrina del "no plazo", pues afirma de modo terminante que el plazo razonable no se puede medir en "días, semanas, meses o años", sino que, en todo caso, concluido el proceso será analizada la razonabilidad de su duración mediante ciertos criterios de examinación, ni únicos ni precisos, que permitirán al evaluador afirmar si el proceso ya cerrado ha sobrepasado la extensión máxima tolerada por el derecho. Esos axiomas de apreciación, por lo demás no taxativos, son, en lo fundamental, la prolongación efectiva del proceso (contada desde la detención del imputado o desde el primer acto oficial de persecución contra él hasta la finalización total del proceso agotados todos los recursos disponibles e intentados), la gravedad del hecho (y, por ello, de la pena prevista y últimamente también - muy objetablemente - de la culpabilidad del acusado), la complejidad de la investigación y la prueba, la conducta del imputado durante el enjuiciamiento y el comportamiento de las autoridades encargadas de llevar adelante el proceso hasta la sentencia definitiva firme. Estas pautas laxas no brindan precisión alguna ni permiten una fiscalización seria que soporte las exigencias propias del principio del Estado de derecho como límite de la legitimidad del ejercicio del poder penal. El criterio de la opinión dominante permite ver con evidencia que detrás de la declaración de que la razonabilidad se estudia bajo estos criterios vagos y ambiguos sólo existe una carte blanche para que quien decida sobre la razonabilidad lo pueda hacer libremente, sin más ataduras que las de sus predilecciones discrecionales. Por ello, aun en los casos en que las predilecciones de la jurisprudencia se inclinaron por declarar la violación del plazo razonable no se estableció con precisión el momento a partir del cual, un proceso ya finalizado, había superado su duración máxima tolerable.

En cambio, esta opinión dominante sí ha sido precisa respecto de la determinación de las consecuencias jurídicas de la violación del derecho fundamental del acusado a ser juzgado dentro de un plazo razonable: la lesión debe ser reparada. Para los organismos internacionales esta era la única alternativa, en principio, frente a la violación del derecho (doctrina de la "cuarta instancia"), pero es altamente llamativo que también los tribunales del proceso la hayan adoptado, pues ellos sí pueden definir el enjuiciamiento y, por tanto, hacer valer otras consecuencias por la lesión de este derecho fundamental ya en el momento de producirse. No obstante, prefirieron la salida compensatoria y así, además de importar la doctrina del "no plazo", adoptaron también la idea de compensar la superación del plazo razonable, ya sea en moneda de atenuación, suspensión de la ejecución o prescindencia de la pena, en virtud de la compensación de la culpabilidad por el hecho que representa un proceso de duración anormal, o bien por vía de la remisión al poder competente para que considere dicha circunstancia a los fines de indultar, conmutar o remitir condicionalmente la pena, aunque también, en ocasiones, se ha transferido la cuestión al resarcimiento civil de los daños causados por la violación del derecho involucrado y a la sanción disciplinaria y, dado el caso, penal de los funcionarios culpables de los retrasos.

Esto es, entonces, aquello a lo cual la opinión dominante ha reducido el derecho de toda persona imputada de un delito a ser juzgada dentro de un plazo razonable: un manojo de pautas genéricas previstas para examinar expost indicium si un proceso tuvo una 
duración razonable con miras a, en caso negativo, compensar de alguna manera tal violación de un derecho fundamental del acusado.

Contra esa opinión este trabajo ha tratado de demostrar que, por mandato del principio del Estado de derecho y de un correcto entendimiento del sistema de los derechos fundamentales de los individuos, es obligatorio tomar otro camino.

La idea central es que el plazo razonable sea interpretado, en primera línea, como aquello que el derecho procesal penal comprende por plazo: un lapso dentro del cual $-\mathrm{y}$ sólo dentro del cual- un acto procesal, un conjunto de actos procesales, una etapa del procedimiento o todo el proceso (como conjunto de todos los actos particulares que lo componen) pueden ser realizados válida y eficazmente. Dicho plazo, como cualquier plazo, debe estar establecido en las unidades temporales que el derecho, como fenómeno cultural, ha adoptado en reconocimiento del hecho histórico y social de la organización del tiempo entre los seres humanos: días, semanas, meses, años. Además, el plazo en cuestión debe ser establecido por el legislador de un modo general y abstracto. Ello se justifica porque todo el proceso es una coacción estatal que menoscaba derechos de las personas sometidas al enjuiciamiento (desde soportar la mera obligación de tolerar el proceso y todas sus medidas hasta la prisión preventiva) y esa coacción sólo es legítima si está autorizada por la ley dentro de unos límites precisos, entre los cuales están incluidos también sus contornos temporales (no hay coacción sin ley [nulla coactio sine lege]). Esa idea es el alma del principio del Estado de derecho, en el cual las autoridades únicamente pueden ejercer aquellos poderes que la ley expresamente les otorga y hasta los límites (también temporales) de esa autorización. La regulación por ley del plazo de la extensión máxima del proceso también está impuesta por el principio nulla poena sine lege en tanto se observe y reconozca que el proceso mismo opera ya como una pena "material", aunque informal si se quiere. El plazo legal, por último, evita la manipulación judicial (decisionismo y arbitrariedad) de la razonabilidad de la duración de los procesos al estipular un límite absoluto al poder de enjuiciamiento del Estado que, en cuanto tope máximo, está fuera del alcance de toda interpretación incierta. A los tribunales y a los órganos de control del respeto de los derechos de los tratados internacionales de derechos humanos les compete, únicamente, analizar si los plazos legales —en cuanto plazos máximos, nunca mínimos— son efectivamente razonables.

Este trabajo no brinda recetas o estimaciones concretas acerca de cuál debería ser la extensión de dicho plazo o plazos. Esa determinación requiere, ya se dijo, una amplia investigación empírica previa que otorgue los elementos informativos básicos para conocer con precisión y seguridad (bases de todo pronóstico efectivo) cuáles son los requerimientos temporales atendibles de la administración de justicia penal y cuáles las razones que pueden justificar en algunos casos un tiempo de duración del proceso más prolongado que en otros, aunque siempre dentro de la razonabilidad temporal máxima permitida. Aquí sólo ha sido aportada una matriz sobre la cual la investigación empírica deberá volcar sus conclusiones para completar la fórmula del plazo legal razonable de duración del proceso penal. En ese sentido, este trabajo pretende ofrecerse como hombros austeros sobre los cuales puedan subirse a mirar quienes quieran ver más lejos y enseñarnos un panorama completo acerca de este tema.

En materia de consecuencias, en contra de lo afirmado por la opinión dominante en el sentido de recurrir casi exclusivamente a la compensación, el cumplimiento del plazo razonable conduce a la clausura inmediata y definitiva del proceso. Este es el efecto 
Pastor - Acerca del derecho fundamental al plazo razonable de duración del proceso penal

jurídico que innegablemente se debe desprender, como garantía judicial, de la norma fundamental que pretende evitar que el proceso penal tenga una duración excesiva.

La solución por la compensación de la violación, defendida por la opinión dominante, es cuestionable por su posible incompatibilidad con el principio del Estado de derecho, sistema que muy difícilmente podría consentir que, tras ser reconocida la violación de un derecho fundamental, simplemente se decida dejar inalterada la infracción y su resultado, la continuación del proceso, y sólo estimar disminuido el reproche necesario de la culpabilidad, en razón de la duración excesiva del enjuiciamiento. La solución compensatoria falla, ante todo, porque para poder reaccionar contra la violación de este derecho fundamental exige más violación, en el sentido de que, producida la superación del plazo razonable de duración del proceso, éste, sin embargo, tendrá que durar todavía - excesiva e ilegítimamente - todo lo que sea necesario hasta alcanzar por fin la sentencia definitiva, único momento en el que se le dará alguna relevancia jurídica a dicha lesión de derechos fundamentales.

Es por ello que, para la suerte del proceso, el vencimiento de su plazo máximo de duración razonable debe ser visto como un impedimento procesal que evite la prolongación del enjuiciamiento, dado que, de continuar, se volvería ilegítimo a partir de ese punto en el tiempo. En el derecho procesal penal este impedimento se canaliza a través de la vía de las excepciones o artículos de previo pronunciamiento, con imputación, por analogía in bonam partem, al obstáculo procesal de la prescripción del delito.

En resumen, los plazos de duración máxima razonable del proceso deben ser fijados legislativamente con carácter general y con la consecuencia jurídica de que, al cumplirse, el proceso deba cesar anticipada y definitivamente ${ }^{82}$. Pero esto de ningún modo significa una autorización para que las sentencias materialmente correctas sean alcanzadas, dentro de plazos razonables, a cualquier precio, esto es, a través de instrumentos procesales altamente reñidos con otros derechos fundamentales (condenación "negociada" sin juicio, restricción de las facultades defensivas, privación del derecho del condenado al recurso, acotación excesiva de la inmediación, etc.). Muy por lo contrario, la aceleración de los procesos provendrá de la descarga de las tareas de la justicia que supondrá la clausura de todos aquellos casos que hayan superado la duración permitida. Asimismo, la solución al problema de la congestión de procesos que sobrecarga los tribunales y que impide el enjuiciamiento en tiempos razonables debe encontrar solución también en un reordenamiento racional e inteligente tanto de las necesidades de la reacción punitiva como de los recursos disponibles para atenderlas, hoy en gran medida malversados. Sólo así se podrá conseguir una relación satisfactoria entre tiempo y derecho, desde todas las perspectivas en que se vinculan estas dos instituciones básicas de nuestra cultura. El juzgamiento tempestivo de la sospecha de que se ha cometido un delito, dentro de un plazo razonable pero sin restricción de los demás derechos fundamentales del imputado, permitirá evitar la pérdida de medios probatorios, ahorrar recursos financieros estatales hoy dilapidados en procesos interminables, aumentar la capacidad funcional de la administración de justicia y colmar las expectativas sociales, en gran medida simbólicas, que reclaman para el caso de que se haya cometido un delito una rápida pero lícita declaración de culpabilidad que restablezca la paz jurídica.

${ }^{82}$ Tal como ha sucedido ya, en casi todos los países, con el plazo máximo de duración razonable de la prisión preventiva, derecho fundamental establecido por los mismos catálogos de derechos fundamentales, con los mismos alcances y casi con las mismas palabras con las que imponen el derecho del imputado a ser juzgado dentro de un plazo razonable. 